\title{
Studia
}

SYNCHRONICZNE I DIACHRONICZNE ASPEKTY BADAŃ POLSZCZYZNY

www.wnus.edu.pl/sj | DOI: 10.18276/sj.2016.15-18 | 255-259

BOGDAN WALCZAK

Akademia im. Jakuba z Paradyża

Gorzów Wielkopolski

\section{Paulina Michalska, Status staropolskich oboczności wyrazowych w polszczyźnie doby średniopolskiej, Wydawnictwo Poznańskiego Towarzystwa Przyjaciół Nauk, Poznań 2013, ss. 309}

Praca Pauliny Michalskiej sytuuje się w obszarze historii języka polskiego. Jej przedmiotem są późniejsze losy staropolskich oboczności wyrazowych (przy czym przez wyrazy rozumie tu autorka nie tylko leksemy autosemantyczne, lecz także to, co się czasem określa mianem luźnych morfemów gramatycznych (składniowych) - tutaj przede wszystkim spójniki), ujawnionych w toku dyskusji nad pochodzeniem polskiego języka literackiego. Sama autorka tak charakteryzuje cel swojej pracy:

„Celem niniejszej książki jest próba ustalenia na podstawie materiału zgromadzonego w Słowniku polszczyzny XVI wieku oraz Słowniku języka polskiego XVII i 1. połowy XVIII wieku statusu wywodzących się ze staropolszczyzny jednostek wyrazowych, wyodrębnionych w toku dyskusji o pochodzeniu polskiego języka literackiego jako cechy dyferencjujące polski obszar językowy, w języku literackim doby średniopolskiej - na ile, i czy w ogóle, regionalne właściwości wyrazowe pojawiające się w dyskusji nad pochodzeniem polszczyzny literackiej są rzeczywistymi cechami dyferencjalnymi, na ile zaś cechy te, zwiększając swoje zasięgi terytorialne, stały się w dobie średniopolskiej właściwościami regionalnymi wynikającymi tylko z częstości użycia. Weryfikacja taka będzie także próbą ustalenia, jakie inne, pozageograficzne czynniki warunkowały szesnasto- i siedemnastowieczną ich wariancję. Tym samym przedstawione zagadnienie łączy się z problemem wariantywności polszczyzny literackiej w okresie jej krzepnięcia” (s. 21). 
Podstawę źródłowo-materiałową pracy, jak już wynika z powyższego przytoczenia, stanowią dwa fundamentalne słowniki historyczne, obejmujące łącznie dzieje polskiej leksyki od początku XVI do połowy XVIII wieku. Autorka pisze o tej podstawie, co następuje:

„Bazę materiałową pracy stanowią teksty drukowane i rękopiśmienne powstałe we wszystkich regionach Rzeczypospolitej doby średniopolskiej bądź w regionach z nią związanych [pod tym trochę zagadkowym określeniem kryje się Śląsk i Prusy Książęce, które zresztą do roku 1657 stanowiły jako lenno część Rzeczypospolitej - B.W.], ekscerpowane w sposób pośredni - przez materiał leksykograficzny zawarty w Słowniku polszczyzny XVI wieku oraz Słowniku języka polskiego XVII i 1. połowy XVIII wieku, a także przez stworzone na potrzeby słowników kartoteki wyrazowe i indeksy, ponieważ obydwa dzieła wciąż pozostają nieukończone" (s. 56-57).

Obszerna i wnikliwa charakterystyka obu słowników (s. 60-68), o której jeszcze niżej, dowodzi, że autorka przeprowadziła bardzo sumienną kwerendę w obu stosownych pracowniach leksykograficznych i bardzo skrupulatnie wyzyskała (poza, co oczywiste, częścią opublikowaną i/lub wersją dostępną w Internecie) to wszystko, co zostało w nich zgromadzone w postaci kartotek i różnego rodzaju indeksów. Jako punkt wyjścia wyzyskała też ukończony już Stownik staropolski (opublikowany w latach 1953-2002). W tym kontekście nie ulega dla mnie wątpliwości, że podstawę źródłowo-materiałową rozprawy Pauliny Michalskiej należy uznać za ze wszech miar satysfakcjonującą.

Równie wysoko należy ocenić założenia teoretyczno-metodologiczne rozprawy. Ich prezentacji poświęciła autorka obszerne partie pierwszej części pracy, zatytułowanej Podstawy teoretyczne badań (s. 27-68). Na oryginalne i samodzielnie przez nią skonstruowane instrumentarium badawcze składają się elementy strukturalistycznej metody badań diachronicznych w ujęciu Ireny Bajerowej (w szczególności jej koncepcja wydzielania tzw. przekrojów synchronicznych, twórczo zaadaptowana i rozwinięta przez Wojciecha Ryszarda Rzepkę, i segmentacji procesu normalizacyjnego, rozwinięta i uzupełniona przez Władysławę Książek-Bryłową), a dalej teoria perspektywy paraleli Kwiryny Handke i nierozerwalnie z tymi koncepcjami związana metodologia językoznawstwa statystycznego. W moim przekonaniu jest to instrumentarium prawomocnie tutaj zastosowane i operacyjnie wydajne oraz w pełni adekwatne do przedmiotu rozprawy i jej celu.

Wychodząc z najzwięźlej tu scharakteryzowanych założeń teoretyczno-metodologicznych i uzbrojona w równie zwięźle przedstawione narzędzia, osiągnęła autorka zamierzony cel badawczy. Powstała praca sumienna, solidna, gruntowna i w przyjętym zakresie wyczerpująca. O jej wartości stanowią - w moim przekonaniu - przede wszystkim następujące aspekty i elementy:

1. Adekwatne do przedmiotu rozprawy i jej podstawy źródłowo-materiałowej założenia teoretyczno-metodologiczne i zastosowane instrumentarium badawcze (o czym już była mowa wyżej). Michalska, co godne podkreślenia, odznacza się wysokim stopniem świadomości metodologicznej i rzadką umiejętnością krytycznej oceny konkurencyjnych paradygmatów badawczych lingwistyki. 
2. Samoistna wartość informacyjna Wstępu i Części I, w których autorka precyzyjnie, w sposób głęboko przemyślany i sproblematyzowany, zrelacjonowała rozwój historycznej refleksji na temat zróżnicowania regionalnego polszczyzny, dzieje naukowej refleksji geolingwistycznej (wyodrębnienie się dialektologii jako autonomicznej subdyscypliny językoznawczej, powstanie dialektologii historycznej, stan badań w zakresie geograficznego zróżnicowania leksykalnego polszczyzny), historię dyskusji o genezie polskiego języka literackiego, metody badawcze historii języka polskiego jako działu językoznawstwa diachronicznego, wreszcie problematykę regionalizacji języka. Ta część będzie mogła być z pożytkiem wyzyskiwana w dydaktyce uniwersyteckiej na poziomie seminarium magisterskiego i studiów doktoranckich.

3. Samoistna wartość informacyjna charakterystyki dwu fundamentalnych słowników historycznych: Stownika polszczyzny XVI wieku i Stownika języka polskiego XVII i 1. połowy XVIII wieku. Wprawdzie na ten temat istnieje już literatura naukowa (którą oczywiście badaczka zna i relacjonuje), ale autorka wniosła w tym względzie wiele nowego (bardzo trafna jest jej opinia o drugim z tych słowników, że ,[...] jest to obecnie dzieło leksykograficzne zupełnie innego typu niż pierwotna wersja drukowana”, s. 67) w wyniku bardzo skrupulatnej kwerendy przeprowadzonej w pracowniach obu słowników.

4. Imponujące zaplecze erudycyjne rozprawy. Wykaz bibliograficzny, w którym nie dostrzegam żadnych braków czy pominięć, poza źródłami obejmuje 11 encyklopedii i słowników (etymologicznych, gwarowych, onomastycznych, idiolektalnych itp.) oraz 250 opracowań, w tym prawie 70 książek, nierzadko wielotomowych. Należy przy tym podkreślić, że gruntowna i krytyczna znajomość obszernej literatury przedmiotu (z wieloma tezami przywoływanych autorów badaczka polemizuje, dając świadectwo wielkiej kultury polemicznej) ma w rozprawie Pauliny Michalskiej charakter w wysokim stopniu „sfunkcjonalizowany": jej wyniki, umiejętnie przez autorkę wyzyskane, konstytuują tło i wieloraki kontekst naukowy jej pracy, która dzięki temu zyskuje na głębi i gruntowności.

5. Szczegółowość, precyzja i wszechstronność opisu, analizy i interpretacji. W obszernej Części II, zatytułowanej Analiza materiału (s. 69-282), autorka gruntownie i wszechstronnie opisała zleksykalizowane oboczności fonetyczne i/lub morfologiczne albo/abo,

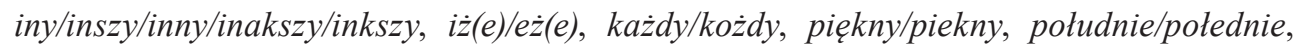
sie-t(e)m/sied(e)m, stryj/stryk, wuj/uj(ek), wszak/wszakoż, wszystek/wszytek/wszyciek, zawsze/zawdży/wżdy/wżda, stricte leksykalne do/k(u), jenże/który i trzymać/dzierżé, a wreszcie mieszane ale/lecz/ali, jedno/jeno/tylko i ponieważ/bo/bowiem/abowiem. Opis każdej oboczności, po wstępnych uwagach wprowadzających, odniesieniach dla literatury przedmiotu itd. obejmuje zaprezentowane tabelarycznie (w bardzo przejrzystych tabelach, operujących liczbami bezwzględnymi i relacjami procentowymi) w dwu przekrojach synchronicznych (XVI wiek i okres od początku XVII do połowy XVIII stulecia) informacje (wielostronnie i wnikliwie skomentowane przez autorkę) o statystycznym rozkładzie regionalnym wariantów według pochodzenia autora tekstu drukowanego, według miejsca wydania, w rękopisach i łącznie w drukach (uporządkowanych według pochodzenia autora) 
i rękopisach. Całość odnoszącą się do określonej oboczności zamyka (również wszechstronnie skomentowana przez autorkę) tabela diachroniczna obrazująca tempo przebiegu procesu normalizacyjnego w poszczególnych regionach. W Podsumowaniu tej części (s. 260-282) zaprezentowała autorka (również tabelarycznie) zbiorcze ujęcie wyników rywalizacji obocznych wariantów w rozkładzie według regionów (poszczególne tabele odnoszą się kolejno do Wielkopolski, Małopolski, Mazowsza, Kresów południowych, Kresów północnych, Śląska i Prus).

6. Zalety eksplikacyjno-kompozycyjne rozprawy, tzn. zalety wykładu i walory układu (przejrzystego i logicznego) pracy. W szczególności chciałbym tu podkreślić znaczenie dwu kwestii: wartości informacyjnej tabel oraz (co szczególnie ważne w Części I) trafnego i głęboko przemyślanego rozkładu informacji między tekst główny i poboczny (przypisy): w przypisach, często bardzo „gęstych” informacyjnie (absolutnie nie do pobieżnego oglądu, nie mówiąc już o pominięciu), autorka pomieściła informacje ważne i interesujące, nieraz zgoła fundamentalne, jednak z perspektywy głównego wywodu - przynajmniej w tym miejscu - drugorzędne; zabieg ten bardzo korzystnie wpływa na płynność zasadniczej narracji naukowej.

7. Użyteczność (z której zdaje sobie sprawę sama autorka) rozprawy dla polonistycznej dydaktyki akademickiej.

8. I wreszcie, jako skutek wszystkich wyliczonych wyżej walorów, interesujące i ważne wyniki naukowe. Jest ich wiele, zwłaszcza szczegółowych (dla historyka języka polskiego interesujące jest każde szczegółowe ustalenie autorki) i niepodobna tu wymienić nawet relatywnie najważniejszych. Jedynie tytułem przykładu przytoczę dwa spośród najogólniejszych wniosków: „Oboczności regionalne wykorzystywane jako argument w głównym nurcie dyskusji o pochodzeniu polskiego języka literackiego nie funkcjonują już w odniesieniu do doby średniopolskiej jako regionalizmy” (s. 283) i „Wydaje się, że regionalizm leksykalny typu dyferencyjnego jest cechą językową występującą może nie tyle rzadko, co raczej przez stosunkowo krótki czas, gdyż upowszechniając się, przeobraża się w regionalizm oparty na frekwencji. Proces ten wynika ze specyfiki doby średniopolskiej, m.in. rozwoju drukarstwa, wzmożonej migracji pisarzy, a w konsekwencji - z łatwiejszego rozprzestrzeniania się cech językowych pierwotnie regionalnych” (s. 284).

9. Na koniec koniecznie trzeba podkreślić formalne walory rozprawy: nieskazitelną pisownię (łącznie z interpunkcją, co jest już dzisiaj ewenementem zasługującym na szczególne uwypuklenie), sprawną i poprawną (Michalska wie nawet (czego już dziś nie wie prawie nikt), że imię łódzkiego językoznawcy Szlesińskiego Iwo odmienia się: Iwo, Iwona, Iwonowi itd.) (s. 20) polszczyznę w odmianie naukowej (którą autorka, dobra stylistka, włada ze swadą, szczęśliwie łącząc precyzję z jednej, a swobodę z drugiej strony), wreszcie wyjątkowo staranną redakcję rozprawy (wzorowo konsekwentne wyróżnienia typograficzne, równie stosowny i konsekwentny zapis bibliograficzny (w przypisach i Bibliografii ) itd. (co już jest jednak także zasługą wydawnictwa). 
Bogdan Walczak | Paulina Michalska, Status staropolskich oboczności wyrazowych... | 259

Z wyłuszczonych wyżej względów praca Pauliny Michalskiej Status staropolskich oboczności wyrazowych w polszczyźnie doby średniopolskiej wpisuje się na listę podstawowych lektur historyka języka polskiego. 
